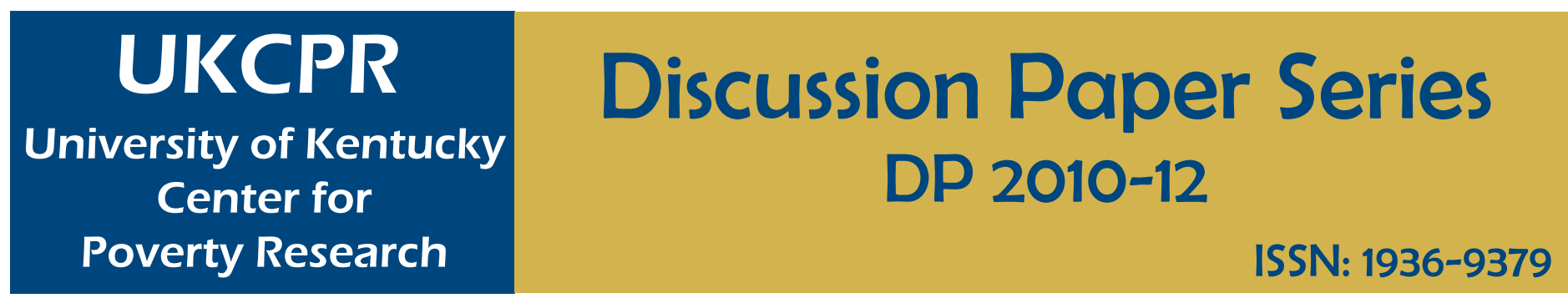

\title{
Imprisonment and (Inequality in) Population Health
}

\author{
Christopher Wildeman \\ Assistant Professor of Sociology \\ Department of Sociology \\ Yale University \\ Postdoctoral Affiliate \\ Population Studies Center \\ University of Michigan
}

Preferred citation

Wildeman, Christopher. (2010). Imprisonment and (Inequality in) Population Health. University of Kentucky Center for Poverty Research Discussion Paper Series, DP2010-12. Retrieved [Date] from http://www. ukcpr.org/Publications/DP2010-12.pdf.

Author correspondence

Christopher Wildeman, University of Michigan, School of Public Health, 3648 SPH Tower, 109 Observatory, Ann Arbor, MI 48109. E-mail: wildeman@umich.edu

University of Kentucky Center for Poverty Research, 302D Mathews Building, Lexington, KY, 40506-0047 Phone: 859-257-7641; Fax: 859-257-6959; E-mail: mary.boulton@uky.edu

\section{www.ukcproorg}




\title{
Imprisonment and (Inequality in) Population Health
}

\section{Imprisonment and (Inequality in) Population Health}

\author{
Christopher Wildeman ${ }^{1}$ \\ University of Michigan
}

Word Count: 9,563

Key Words: Mass Imprisonment; Stratification; Population Health; Health Disparities

\footnotetext{
${ }^{1}$ Direct mail to Christopher Wildeman, University of Michigan, School of Public Health, 3648 SPH Tower, 109 Observatory, Ann Arbor, MI 48109. Direct email to wildeman@umich.edu. This research was supported by a postdoctoral fellowship from the Robert Wood Johnson Foundation Health \& Society Scholars Program, a small grant from the Robert Wood Johnson Foundation Health \& Society Scholars Program at the University of Michigan, and a grant from the UK Center for Poverty Research through the U.S. Department of Health and Human Services, Office of the Assistant Secretary for Planning and Evaluation, grant number 5 U01 PE000002-06. The opinions expressed herein may not represent those of funding agencies. Kevin Bradway provided excellent research assistance. Chris Muller, Sarah Burgard, Jason Schnittker, Jason Beckfield, Bruce Link, Andy Papachristos, Hedy Lee, Jeff Morenoff, Carol Ann MacGregor, Jim Ziliak, Chris Bollinger, Rich Fording, Josh Guetzkow, Dan Black, Seth Sanders, Brea Perry and Ebonya Washington provided helpful comments on prior versions of this manuscript.
} 


\begin{abstract}
This article extends research on the consequences of mass imprisonment and the factors shaping population health and health inequities by considering the effects of the imprisonment rate on population health and black-white inequality in population health using state-level panel data from the United States (1980-2004). My results imply that increases in the imprisonment rate harm population health, though the effects on the infant mortality rate and female life expectancy are more consistent than are the effects on male life expectancy. My results also imply that these health effects are concentrated among blacks, implicating mass imprisonment in the persistence of black-white inequities in population health. The effects, moreover, are substantial. According to my estimates, if the American imprisonment rate had remained at its 1980 level, black life expectancy at birth would have been 0.8 years longer in 2004, and black-white inequality in the infant mortality rate would have been 23 percent smaller. My results also indicate, however, that increases in the imprisonment rate are associated with decreases in the mortality rates of young black men. Although imprisonment's long-term effects on health and health inequities are mostly negative, imprisonment may, in the short-run, have some health benefits for young black men.
\end{abstract}


For the first three-quarters of the $20^{\text {th }}$ century, the American imprisonment rate was noteworthy mainly for its stability (Blumstein and Cohen 1973). Since then, it has become better known for its rate of growth and comparatively extreme level. By 2005, the American imprisonment rate exceeded 500 per 100,000, a far cry from its modest rate of 100 per 100,000 in the early 1970s. Dramatic levels of imprisonment among young black men with low education are another distinguishing feature of American imprisonment (Pettit and Western 2004; Wacquant 2001). Well over 60 percent of such men can expect to have ever been imprisoned by their mid-30s (Pettit and Western 2004; Western and Wildeman 2009: 231). In light of dramatic increases and vast disparities in the risk of imprisonment, a growing literature considers the consequences of imprisonment for individuals, families, communities, and inequality (see reviews of Clear 2008; Comfort 2007; Wakefield and Uggen Forthcoming; Wildeman and Western Forthcoming).

Unfortunately, little is known about the macro-level effects of imprisonment on health and health inequities (Beckfield and Krieger 2009:157; Wakefield and Uggen Forthcoming; but see Wildeman 2009a). This inattention is regrettable for at least three reasons. First, population health—measured as life expectancy at birth and the infant mortality rate—and inequality in population health yield insight into population wellbeing and stratification (Beckfield 2004; Conley and Springer 2001; Hall and Lamont 2009; LaVeist 1992). Second, given the negative effects of imprisonment on families and communities (Clear 2008; Comfort 2007) and the constraints that corrections spending places on state budgets (Ellwood and Guetzkow 2009), the effects of mass imprisonment may actually be greater for the never-imprisoned than for the everimprisoned. Yet no research directly tests this possibility. The outcomes considered here provide an opportunity to decipher whether the health effects of imprisonment concentrate among the men most likely to go to prison or the women and children they leave behind. Finally, despite 
high homicide risks among young black men, no research tests the effects of the imprisonment rate on young black men's mortality risks. As such, our understanding of the direction of imprisonment's effects on the health of the men most likely to be imprisoned is incomplete.

This article takes a first step toward considering these relationships using state-level panel data from the United States covering the years 1980 to 2004. My results suggest that increases in the imprisonment rate compromise population health, though the effects on the infant mortality rate and female life expectancy are more consistent than are the effects on male life expectancy. This suggests that the health effects of imprisonment may be more substantial for the women and children left behind than for the men for whom imprisonment has become common. My results also imply that the health effects of imprisonment are concentrated among blacks, implicating mass imprisonment in the persistence of health inequities. Furthermore, the effects are substantial. Based on my estimates, had the American imprisonment rate remained at the 1980 level, black life expectancy at birth would have been 0.8 years longer in 2004, and black-white inequality in the infant mortality rate would have been 23 percent smaller. My results also imply, however, that increases in the imprisonment rate are associated with decreases in the mortality rates of black men in their early 20s. This finding is provocative since it implies that imprisonment may have some short-term health benefits for young black men.

\section{THE SOCIAL PATTERNING OF MASS IMPRISONMENT}

As the American imprisonment rate has increased, researchers have started to consider change and disparities in the lifetime risk of imprisonment. Research in this area reaches a number of conclusions relevant for scholars of health. First, 11.3 percent of all American men can expect to experience imprisonment at some point in their lives — a massive increase over the 3.6 percent 
who could expect to ever experience imprisonment in the mid-1970s (Bonczar 2003). Second, 20 to 25 percent of black men from recent birth cohorts can expect to be imprisoned at some point in their lives (Pettit and Western 2004; Western and Wildeman 2009). The risk for white men pales in comparison; only around three percent can expect to ever go to prison. Finally, imprisonment is now a modal experience in the life-course of black men with little schooling (Pettit and Western 2004; Western and Wildeman 2009). Therefore, if having ever gone to prison influences health, the penal system may have an important influence on health inequities.

Although mass imprisonment could have substantial effects on health inequities among adult men, the consequences of mass imprisonment for health may end there if ever-imprisoned men have little to do with their families or harm them when they do. Men who go to prison at some point, however, not only have children, but also tend to be engaged in family life—at least some of the time. Since the onset of the prison boom, the risk of paternal imprisonment has grown for children as it has for adult men (Wildeman 2009b). Though some of these men were absent from their children's lives before going to prison, most ever-imprisoned men want to be involved in family life (Braman 2004; Comfort 2007, 2008) and see their involvement with the criminal justice system as impeding their attempts to do so (Goffman 2009). Thus, existing research in this area indicates that mass imprisonment may have substantial macro-level effects on population health and health inequities if having a family member go to prison affects health.

\section{MASS IMPRISONMENT AND (INEQUALITY IN) POPULATION HEALTH}

In the next three sections, I consider the health consequences of imprisonment. First, I review existing research on the effects of imprisonment on men's health. Second, I focus on the broader 
health effects of mass imprisonment for families, communities, and populations. Third, I discuss the possible short-term benefits of imprisonment for the mortality rates of young black men.

\section{Direct Health Effects of Imprisonment}

Researchers have long been interested in the health effects of incarceration and release. Most research in this area has focused on the consequences of incarceration and release for mortality (Binswanger et al. 2007; Clavel, Benhamou, and Flamant 1987; Farrell and Marsden 2007; Mumola 2007; Rosen et al. 2008). In general, research in this area finds that individuals have lower mortality while incarcerated than those on the outside who are similar on key demographic indicators such as age, race, and sex (Clavel et al. 1987; Mumola 2007) but higher risks than similar individuals upon release, especially immediately after release (Binswanger et al. 2007; Farrell and Marsden 2007; Rosen et al. 2008). It remains unclear based on these studies whether incarceration or release are responsible for these differences in mortality rates - in large part because prisoners are matched with controls only on age, race, and sex. Likewise, it remains unclear whether the mortality costs of imprisonment outweigh any mortality benefits since no study follows comparable ever- and never-imprisoned men throughout the life course.

Research on the broader health consequences of having ever been incarcerated, however, provides more robust estimates of the effects of incarceration on health. Specifically, studies show that having ever been incarcerated increases one’s risk of having infectious or stressrelated diseases (Massoglia 2008a; Massoglia and Schnittker 2009) and severe functional limitations (Schnittker and John 2007). Since these health problems may elevate mortality risk, this research implies that once the ever-incarcerated have been released, they may be at greater mortality risk than comparable individuals and that their status as ex-prisoners is partially 
responsible for this elevated risk. Thus, based on these studies of the broader health effects of having ever been imprisoned, we might expect imprisonment to be associated with diminished health for men. Since black men are much more likely than white men to ever go to prison, we might also expect that these effects would increase black-white inequality in health among men.

\section{Imprisonment and (Inequality in) Population Health}

Since only 11 percent of American men ever go to prison (Bonczar 2003), however, for the penal system to have large effects on population health, effects of imprisonment must extend beyond these men. Little research considers such population health effects, but research on the effects of imprisonment on families, communities, and populations implies that the effects of mass imprisonment on population health and health inequalities may be substantial. Furthermore, the little existing in this area suggests that mass imprisonment has negative effects on population health. Although this study provides but a glimpse into the implications of mass imprisonment for population health because it considers a relatively short time period (1990-2003) and only considers infant mortality, it nonetheless demonstrates that (1) increases in the imprisonment rate are associated with higher infant mortality rates and greater black-white inequities in the infant mortality rate and (2) parental incarceration increases the risk of infant mortality in a sample of at-risk infants (Wildeman 2009a). Thus, the little existing research-especially combined with an expansive literature on the collateral consequences of mass imprisonment-indicates that the effects of imprisonment on health and health inequities extend much further than once thought.

In this section, I suggest that mass imprisonment compromises population health through two main avenues. First, incarceration compromises the health of family members and romantic partners both directly (via infectious disease) and indirectly (via socioeconomic status). Effects 
may also spill out into the community, though the evidence here is less clear-cut (Clear 2008). Second, since state spending on corrections may diminish some forms of welfare state spending (Ellwood and Guetzkow 2009) and welfare state spending tends to promote population health (Beckfield and Krieger 2009; Conley and Springer 2001), this tradeoff may compromise the health not only of those directly connected to prisoners or former prisoners, but also the entire population. To the degree that mass imprisonment diminishes welfare state spending in areas most directly relevant to the poor, its effects on health inequities could also be substantial.

Probably the most transparent channel through which imprisonment could decrease the health and wellbeing of a population—and increase inequality in health and wellbeing —is by increasing the burden of disease of the romantic partners of ever-incarcerated men. Research shows that imprisonment drastically increases the risk of having a variety of infectious diseases (Massoglia 2008a; Massoglia and Schnittker 2009). Since many former prisoners return to their romantic partners upon release, if imprisonment increases infectious disease prevalence among these men, it likely also increases infectious disease prevalence among their partners. Although there is no research that directly examines this possibility, state-level research demonstrates that increases in the imprisonment rate are associated with increases in the AIDS prevalence rates of both men and women (Johnson and Raphael 2009; see also Thomas and Torrone 2006).

In addition to these direct channels, mass imprisonment might also compromise health through a host of indirect pathways, nearly all of which work through incarceration's effects on family socioeconomic status (SES). Research shows that having a family member imprisoned has negative effects on labor market outcomes and relationship stability—-though effects on stress and mental health are also notable. The effects of imprisonment on labor market outcomes are well-known (Pager 2003; Western 2002, 2006), but effects on the resources available to 
families have only recently been documented (Geller, Garfinkel, and Western Forthcoming). And though scholars focus on the pecuniary costs of having a prison record on employment, the non-pecuniary costs of imprisonment—most importantly in the form of diminished health insurance-may also imperil health. Additionally, incarceration could harm health by diminishing the stability of marital unions (Lopoo and Western 2005). Research also indicates that the stigma of having a family member imprisoned diminishes women's social support, thereby compromising their mental health (Braman 2004; Green et al. 2006). For families who have a family member cycling through the penal system, this cycle may contribute to chronic stress, which has well-known effects on health and health inequalities (e.g., Geronimus 1992). ${ }^{2}$ Research on the effects of high rates of imprisonment on neighborhoods paints a similar picture, as it indicates that high rates of imprisonment may diminish community-level social controls, thereby compromising not only community safety, but also community health (Clear 2008).

The mechanisms discussed thus far yield insight into the effects of being incarcerated, having a family member incarcerated, or living in a community in which incarceration is endemic on health. As such, they point toward the population-level effects of imprisonment on the health of the groups most likely to come into contact with prisons. Yet imprisonment may have important effects on the health of all individuals in a population. For instance, research on countries that also experienced massive increases in the imprisonment rate shows that these changes in the imprisonment rate help explain increases in TB prevalence and the robustness of TB strains (Stuckler et al. 2008), implying far-reaching health effects of mass imprisonment.

\footnotetext{
${ }^{2}$ This is not to say that having a family member incarcerated harms all families equally, however. Though little research considers how the effects of parental incarceration vary based on the characteristics of the incarcerated individual, some suggests that negative effects of parental incarceration on child wellbeing are concentrated among families in which the parent was neither abusive nor incarcerated for a violent crime (Wildeman Forthcoming).
} 
Yet this is not the only channel through which mass imprisonment may harm the health of those who never come into contact with the penal system. As the incarceration rate has grown, so has corrections spending (Ellwood and Guetzkow 2009). Since these increases in corrections spending sap public resources, they may diminish spending that promotes health. Little research considers this relationship, but the existing research demonstrates that increases in corrections spending diminish spending on welfare-and contribute to comparably large but nonsignificant decreases in public expenditures on health. Furthermore, these effects are substantial. Each \$1.00 increase in corrections spending leads to about a \$1.40 decrease in welfare spending or public expenditures on health (Ellwood and Guetzkow 2009:232-233). By diminishing state expenditures on public goods, investment in penal institutions may compromise population health. Since spending in these areas may be most consequential for the health and wellbeing of the poor, these changes in spending may also increase inequities in population health.

\section{Paradoxical Health Benefits of Imprisonment}

Despite generally negative effects on health, imprisonment may have some paradoxical benefits for population health. For example, research documents the high rates of homicide victimization among young black men and the effects of this high homicide burden on their life expectancy at birth (e.g., Harper et al. 2007). Imprisonment may therefore diminish population-level mortality rates among young black men in two ways. First, prisoners are at low mortality risk while imprisoned - though analyses to date have yet to provide an appropriate comparison group matched not just on age, race, and sex, but also on criminal activity, poverty, and other relevant covariates (Clavel et al. 1987; Mumola 2007). Thus, increases in the imprisonment rate could diminish mortality rates for young black men by keeping them out of harm's way_albeit behind 
bars. Second, since individuals involved in a homicide tend to resemble one another on a host of demographic characteristics (e.g., Papachristos 2009), increases in imprisonment may not only diminish mortality rates for prisoners but also for their potential homicide victims — who are also disproportionately young black men. In short, increases in the imprisonment rate may reduce the mortality rates of the young black men for whom homicide mortality risk is exceptionally high.

This review leaves us with three broad questions concerning the effects of imprisonment on population health and health inequalities. First, is the imprisonment rate negatively associated with population health? Based on existing research, I expect it is. Second, is the imprisonment rate more negatively associated with population health for blacks or whites? A corollary of this question is whether increases in the imprisonment rate are associated with increases in blackwhite health inequities. Based on existing research, I expect that the imprisonment rate is more negatively associated with population health for blacks than whites and is thereby associated with increasing racial health inequities. Third, are increases in the imprisonment rate associated with short-term decreases in the mortality risk of young black men? Existing research suggests that this is the one group for which increases in the imprisonment rate may diminish mortalityalbeit only in the short-term. For scholars of the collateral consequences of mass imprisonment, it is also worth considering whether the health effects of imprisonment are concentrated among the men most likely to cycle through the system or the women and children they leave behind.

\section{DATA, MEASURES, AND ANALYTIC STRATEGY}

\section{Data}

I use an unbalanced panel dataset of American states covering the years 1980 to 2004 to test my hypotheses ( $N=695)$. In constructing this dataset, I had two exclusion criteria. First, any year in 
which a state was missing on any independent variables was excluded. Second, any state-year that did not produce stable estimates of the infant mortality rate, life expectancy at birth, or agespecific mortality rates for blacks or whites was excluded. After applying these criteria, the sample contains data from 32 states (though not all states contribute an observation each year). These states represent 91.5 percent of the American population in 2004. Thus, though I lose numerous states, I retain coverage of the vast majority of the United States population. ${ }^{3}$

\section{Measures}

Dependent Variables. I use three dependent variables: Measures of life expectancy at birth, the infant mortality rate, and age-specific mortality rates. Life expectancy at birth provides a broad overview of the wellbeing of a population (Beckfield 2004; Hall and Lamont 2009). The infant mortality rate is considered an excellent indicator of the health of women of childbearing age and their infant children (Conley and Springer 2001; LaVeist 1992). Age-specific mortality rates yield insight into the age patterning of the mortality costs and benefits of imprisonment. Since the associations between imprisonment and health may vary by sex, I also consider both life expectancy and age-specific mortality rates by sex. State-level estimates of life expectancy for the total, black, and white populations are available through the Census Bureau only every ten years, so I constructed estimates of life expectancy using life table methods and data on deaths and population size (by age, race, and sex) from the CDC. These estimates lined up closely with Census estimates for 1980, 1990, and 2000. In the interest of consistency, I also used CDC data to estimate the infant mortality rate and age-specific mortality rates. I use measures of life

\footnotetext{
${ }^{3}$ In supplementary analyses, I tested the effects of imprisonment on total life expectancy at birth and the infant mortality rate in all states regardless of whether they produced estimates of population health for blacks or whites. These analyses showed that excluding those states did not drastically alter the relationships considered herein.
} 
expectancy and the infant mortality rate for the total, black, and white populations. I also predict inequality (measured as the difference between blacks and whites) in all four outcomes.

Figure 1 illustrates the broad changes in life expectancy at birth and the infant mortality rate for the total, white, and black populations over the period under study. The three panels on the left of the figure show the substantial gains in life expectancy at birth for the total, black, and white populations between 1980 and 2004; the three panels on the right of the figure show the substantial decreases in the infant mortality rate that were experienced over the same period. ${ }^{4}$ Although improvements in population health for both measures are noteworthy, the continued poor health of blacks relative to whites also merits attention. The black-white gap in population health declined somewhat over this period, yet a substantial, stubborn gap remained in 2004 .

[Insert Figure 1 about here.]

The final dependent variables are age-specific mortality rates (ages <1, 1-4, 5-9, 10-14, 15-19, 20-24, 25-34, 35-44, 45-54, 55-64, 65-74, 75-84, and 85). Though the analysis herein considers the effects of the imprisonment rate on all 13 age-specific mortality rates, emphasis is placed on the effects of the imprisonment rate on the mortality rates of the young men most at risk of homicide and imprisonment. Figure 2 illustrates why the effects of the imprisonment rate on the mortality rates of young black men are especially intriguing, as it documents how much higher the mortality rates of young black men are than the rates for young white men. These differences are most pronounced during the crack epidemic of the late 1980s and early 1990s, but substantial black-white disparities in young men’s mortality rates were noteworthy throughout the study period. Given their high risks of (mostly preventable) mortality, any potentially protective effects of imprisonment on the mortality risks of young black men merit investigation.

\footnotetext{
${ }^{4}$ Although I do not show trends by sex, improvements in life expectancy were similar for men and women.
} 
[Insert Figure 2 about here.]

Explanatory Variable. The explanatory variable is the imprisonment rate in the previous year and is measured per 1,000 state residents. I use the imprisonment rate in the previous year because my estimates of the imprisonment rate are based on year-end estimates of the penal population from the Bureau of Justice Statistics. Thus, a more contemporaneous measure would not have established appropriate time-ordering of events. By using the imprisonment rate in the previous year to predict population health in the current year, I provide insight only into the immediate effects of imprisonment on population health. ${ }^{5}$ Although I use the imprisonment rate as my explanatory variable, a measure of incarceration (which counts individuals detained in local jails as well as prisons) likely would have produced similar results since state-level changes in imprisonment and incarceration generally followed closely in step and incarceration likely also has negative effects on individuals, families, communities, and populations. Unfortunately, the Bureau of Justice Statistics did not publish race-specific imprisonment rates by state for the entire study period. Thus, I focus only on the total imprisonment rate in any given state. As Figure 3 illustrates, there were substantial secular increases in the imprisonment rate between 1980 and 2004. More crucially for the analysis herein, there are also vast differences in imprisonment rates between states, and these differences grew substantially over this period.

[Insert Figure 3 about here.]

Control Variables. This analysis also includes a host of controls. The most important of these are state-level probation, crime, and homicide rates. Adjusting for the probation rate is crucial because doing so yields insight into how the punishment standard for many low-level crimes (such as low-level possession of narcotics) before the prison boom influences population

\footnotetext{
${ }^{5}$ The results were robust to including longer lags and moving averages of the imprisonment rate, however.
} 
health. I adjust for the homicide rate because homicide is both a crime and a cause of death. Thus, it is likely associated with the dependent and explanatory variables. I adjust for the total crime rate because it yields insight into levels of criminal activity, marginalization, and policing. In some preliminary models, I also adjusted for the violent crime rate, but doing so did not substantively alter my estimates or improve model fit, so I did not include it in the final models.

In addition to adjusting for probation, crime, and homicide rates, I also adjusted for a host of other covariates likely associated with the imprisonment rate and population health. These include the following: total public expenditures on health (in 1000s of 2005 dollars); the percent of the population residing in an urban area and that is foreign-born, Hispanic, or black; the age distribution of the population (percent ages $0-14,15-34,35-54$, and 55 or older); the percent of the population at least 25 years of age that had a college degree; gross state product (in 1000s of 2005 dollars per capita); the unemployment rate; AFDC/TANF cases (per 1,000 state residents) and AFDC/TANF plus Food Stamp benefit for a family of four (in 100s of 2005 dollars per month); the percent of the population living in poverty; doctors (per 100,000 state residents); the percent of births that were nonmarital, premature, or low birthweight; whether the state had a Democrat governor; and the percent of the upper and lower houses controlled by Democrats. All of these controls are important, but the last three measures may be especially vital because political alignments may influence both penal policy (Beckett 1997; Jacobs and Helms 2003; Sutton 2000; Yates and Fording 2005) and other policies that affect population health. Results were robust to a series of alternate specifications in which some of these measures were omitted. Despite adjusting for a host of relevant covariates, the analysis herein does not include any measures of state-level drug use, addiction, or availability because of how little reliable data there is considering changes in these factors over time at the state level. This is unfortunate since 
one could argue that it may be changes in the severity of drug abuse or the availability of drugs that was responsible for any association between the imprisonment rate and population health. The main results do not adjust for drug use or abuse, but I do adjust for the severity of the crackcocaine epidemic in a series of robustness checks (Fryer et al. 2005 discusses the construction of the crack-cocaine index). Since there is consensus that the crack-cocaine epidemic was far and away the most relevant change in the availability of drugs and the severity of drug addiction and abuse, if the findings are robust to including this measure, that should increase our confidence in the association between imprisonment and population health. Adjusting for the crack-cocaine index did not substantially alter the relationships shown here. Furthermore, when including this covariate did substantially alter the relationships between imprisonment and (inequality in) population health, it tended to increase the magnitude and significance of these associations. Since including this control would have limited the analysis to the years 1980 to 2000 and did not substantially alter my findings, I opted to preserve the additional four years of data.

For all descriptive statistics and a complete list of data sources utilized, see Table 1. [Insert Table 1 about here.]

\section{Analytic Strategy}

The method utilized is an OLS regression model with state and year fixed effects and an AR(1) adjustment. ${ }^{6}$ This method is appropriate when the data show significant autocorrelation (which they do) and models including both random and fixed effects produce significantly different

\footnotetext{
${ }^{6}$ Since some suggest that including an AR(1) adjustment may significantly bias standard errors in analyses similar to the ones that I am conducting (Bertrand, Duflo, and Mullainathan 2004), I also ran the models with clustered standard errors rather than an AR(1) adjustment. Doing so did not significantly alter the effects of the imprisonment rate on population health — though it did lead to much more statistically significant associations—so I chose to use the more conventional strategy of diminishing concerns about serial correlation using an AR(1) adjustment.
} 
estimates than models including only fixed effects according to a Hausman test (Halaby 2004; see also Beckfield 2006). ${ }^{7}$ I used state fixed effects in addition to controlling for observed statelevel factors because doing so diminishes concerns about unobserved heterogeneity between states driving any observed association between imprisonment and population health. I used year fixed effects because doing so provides a more precise account of how population health evolved over the study period than including a linear control for the year does. Unfortunately, estimates using this method are inconsistent when the number of panels is small (Nickell 1981). Since the average number of observations per state is 20.6, however, my estimates should not be biased by the small number of panels. Results were robust to using a first differences approach, though some of the relationships were less significant. Despite the benefits of first differences, I ultimately settled on the OLS model with state and year fixed effects and an AR(1) adjustment because this model does not exacerbate measurement error, which first difference models do. Though this rigorous modeling strategy in combination with extensive controls take us some of the way toward considering any relationships uncovered here to be causal, it is quite difficult to confidently reject the null hypothesis in this case—especially absent an exogenous shock in imprisonment. Thus, a good deal of caution is in order when interpreting the results shown here. In the first stage of the analysis, I predict four measures of total population health, three related to life expectancy—-total, male, and female life expectancy at birth—and the infant mortality rate (Table 2). The goal in this stage is to consider how the imprisonment rate associates with total population health. In the second stage, I consider the association between the imprisonment rate and the same four measures of population health for whites and blacks (Table 3). The final models in this stage consider the effects of the imprisonment rate on black-

\footnotetext{
${ }^{7}$ I considered using fixed and random effects simultaneously because doing so improves model efficiency.
} 
white inequality in the same measures of population health. Based on point estimates from the analyses in Tables 2 and 3, I then predict how different population health and inequality in population health would be under the counterfactual scenario in which the imprisonment rate had remained at the 1980 level (instead of increasing to the 2004 level) and all else had stayed at its 2004 level (Table 4). In the final stage, I estimate the relationship between the imprisonment rate and age-specific mortality rates by sex for the total, white, and black populations (Table 5).

\section{RESULTS}

\section{Imprisonment and Population Health}

In Table 2, I present estimates of the association between state-level imprisonment rates and population health in the United States between 1980 and 2004. In the first three models, the outcomes considered are total, male, and female life expectancy at birth. In models considering effects of the imprisonment rate on total life expectancy at birth and female life expectancy at birth, the relationship considered is statistically significant (at the .01 level). According to results from these models, each additional prisoner (per 1,000 state residents) is associated with a decline of between .08 (for the total) and .10 (for women) years of life expectancy. Thus, these results provide preliminary support for the association between the imprisonment rate and population health. Models predicting male life expectancy at birth yield smaller (-.06) and less statistically significant (.10 level) associations, but fall basically in line with these results. ${ }^{8}$

[Insert Table 2 about here.]

\footnotetext{
${ }^{8}$ Though not central to the analysis, it is worth noting that some research shows a negative relationship between state-level unemployment rates and population health (Ruhm 2000). Thus, this macro-level relationship is not startling despite negative individual-level effects of unemployment on health (Dooley, Fielding, and Levi 1996).
} 
The final model in Table 2 considers the association between the imprisonment rate and the infant mortality rate. Consistent with previous research considering a shorter time period (Wildeman 2009a), my results indicate that the imprisonment rate is positively and significantly associated with the infant mortality rate. According to these results, each additional prisoner (per 1,000 state residents) is associated with a .15 (per 1,000 births) increase in the infant mortality rate. Taken together, results imply that the imprisonment rate is negatively associated with various measures of total population health at the state level and that the associations between the imprisonment rate and life expectancy at birth may be stronger for women than for men.

\section{Imprisonment and Inequality in Population Health}

Table 2 considered associations of imprisonment with total population health. In Table 3, I present results from models considering race-specific effects of imprisonment on population health and racial inequality in population health. In the first column, I present estimates of the effects of the imprisonment rate on population health for whites. Although I present coefficients only for the imprisonment rate, all estimates are based on models including the same controls as those shown in Table 2. In general, results from models considering whites show that the effects of the imprisonment rate on the health of whites are more muted than they are for the total population. Effects on total white life expectancy are only marginally significant and smaller than were effects on total population health (-.08 to -.06). And though effects on female life expectancy at birth are significant (at the .05 level), effects on male life expectancy at birth are not even marginally significant. Thus, associations between imprisonment and life expectancy for whites are not as consistent or substantial as they were for the total population. The same is 
not the case for the infant mortality rate, however, as the association between the imprisonment rate and the white infant mortality rate is comparable to the association for the total population.

[Insert Table 3 about here.]

Given the disproportionate representation of African Americans in prisons, effects of the imprisonment rate on population health may be stronger for blacks than for whites. In the second column of Table 3, I present associations between the imprisonment rate and population health for blacks. Results show more substantial effects of imprisonment on life expectancy for blacks than whites. While the relationship between imprisonment and population health was small (-.06) and marginally significant for whites, the relationship is much larger (-.23) and statistically significant (at the .01 level) for blacks. Effects are also larger for black male and female life expectancy at birth, which is unsurprising in light of how much more substantial effects on total black life expectancy were than effects on total white life expectancy, although they are (again) only marginally significant for men. Effects on the black infant mortality rate were even more profound. The relationship between the imprisonment rate and the black infant mortality rate is not only statistically significant (at the .05 level), but also substantial: Each additional prisoner (per 1,000 state residents) is associated with an increase of .61 (per 1,000 births) in the black infant mortality rate. To put the magnitude of this relationship in context, consider that the average yearly decline in the infant mortality rate was .23 (per 1,000 births) over this period.

Based on results from the first two columns in Table 3, it would be unsurprising if imprisonment was associated with increased black-white inequality in population health. In the final column of Table 3, I present estimates of the association between the imprisonment rate and black-white inequality in population health. The results suggest that imprisonment is associated with significant increases (at the .05 level) in black-white inequality in life expectancy at birth, 
as each additional prisoner (per 1,000 state residents) is associated with an increase in the blackwhite gap in life expectancy at birth of .14 years. Results are nonsignificant for inequality in male and female life expectancy, however. Based on previously discussed results, it should be unsurprising that the imprisonment rate is positively associated with inequality in the infant mortality rate. Each prisoner (per 1,000 state residents) increase is associated with an increase in the black-white gap in the infant mortality rate of .46 (per 1,000 births). Though the relationship is only marginally significant, this result nonetheless implies possibly substantial effects of the imprisonment rate on inequality in the infant mortality rate. And this result fits nicely with the results presented throughout Table 3, which tend to suggest that total state-level imprisonment rates are more negatively associated with population health for blacks than they are for whites.

\section{Considering the Magnitude of the Imprisonment-Population Health Relationship}

Tables 2 and 3 suggest that the imprisonment rate is negatively associated with population health and inequality in population health, but they provide limited insight into the magnitude of these relationships. In order to provide a sense of the magnitude of these effects, I present estimates of population health and inequality in population health in 2004 under two scenarios. In the first, I hold all covariates at their 2004 levels and predict population health based on these levels and the point estimates from the models shown in Tables 2 and 3. In the second, I hold all covariates at their 2004 levels except the imprisonment rate, which I hold at its 1980 level. This is one way to predict how different population health and inequality in population health would have been had the prison boom not occurred. I also show the observed measures of population health and inequality in population health at 1980. The results from this exercise are shown in Table 4. 
According to my results, had the imprisonment rate remained at the 1980 level instead of increasing to the 2004 level, total, male, and female life expectancy would have been 0.3-0.4 years longer. For total population health, this indicates that absent increases in the imprisonment rate, total population health would have increased about 10 percent more between 1980 and 2004 than it did. For the total infant mortality rate, the story is similar. Had the imprisonment rate remained at the 1980 level, my results imply that the infant mortality rate would have been 0.5 (per 1,000 births) lower. Furthermore, the resulting infant mortality rate would have been nearly seven percent lower than the rate predicted under observed increases in imprisonment (6.9/7.4).

[Insert Table 4 about here.]

The effects were slightly smaller for whites than for the total population. White total, male, and female life expectancy at birth would have been 0.2-0.3 years longer absent increases in the imprisonment rate. And the infant mortality rate would have been about 0.5 (per 1,000 births) lower. For blacks, the effects of changes in the imprisonment rate on population health were markedly larger. My results suggest that black total, male, and female life expectancy would have been 0.6-0.8 years longer in 2004 absent increases in the imprisonment rate. This indicates that the increase in total black life expectancy at birth between 1980 and 2004 would have been about 15 percent greater had the imprisonment rate not increased. Thus, the prison boom appears to have played a substantial role in suppressing increases in black life expectancy over this period. The results are no less striking for the black infant mortality rate. According to my results, the black infant mortality rate would have been 2.2 (per 1,000 births) lower had the imprisonment rate stayed at its 1980 level. Furthermore, my results imply that had the imprisonment rate remained at the 1980 level, the decline in the black infant mortality rate would have been 20 percent greater. The counterfactual exercise suggests that black-white differences 
in total life expectancy at birth would have been 11 percent lower (4.2/4.7) and black-white differences in the infant mortality rate would have been 23 percent lower $(5.3 / 6.9)$ had the imprisonment rate not increased to its 2004 level. Thus, results for inequality echo the earlier estimates, all of which indicate that although imprisonment has negative effects on population health, its effects on the magnitude of disparities in population health may be more substantial.

\section{Age-Specific Effects of Imprisonment on Population Health}

Results to this point have provided insight into how the imprisonment rate influences population health and health inequities, but I have yet to test age-specific effects. Specifically, I have yet to test the hypothesis that increases in the imprisonment rate might actually diminish the mortality rates of young black men. In Table 5, I present estimates of the effects of the imprisonment rate on age-specific mortality rates by sex for the total, white, and black populations.

For the total population of men, my results indicate that the statistically significant effects of the imprisonment rate on age-specific mortality rates are concentrated at the beginning of life. Imprisonment rates are only positively and significantly associated with the mortality rates of males under age one. For the total population of women, effects on age-specific mortality rates are positive and statistically significant in six age ranges: 0-1, 1-4, 10-14; 35-44; 55-64; and 85+. Effects for whites follow a similar pattern to those reported for the total population, with a few exceptions. Perhaps not surprisingly, there were no significant effects of imprisonment on the age-specific mortality rates of white males at the .05 level. (There was one marginally significant protective effect at ages 65-74, but given the large number of models considered and that this relationship barely attained significance at the .10 level, this finding may well be due to chance.) 
For white women, the relationships uncovered mirrored those for the total population of women. Notably, the imprisonment rate never associated with protective effects for white men or women. [Insert Table 5 about here.]

The primary goal of this stage of the analysis was to test whether imprisonment is protective for young black men. Results from models considering the age-specific effects of the imprisonment rate on the mortality risk of black men suggest that increases in the imprisonment rate are associated with substantial, statistically significant (at the .05 level) decreases in the mortality risk of black men ages 20-24. At least for this age group, my results imply that mass imprisonment may have some short-term benefits for population health. Results not shown here (but available upon request) indicate that these benefits are mainly due to diminished homicide mortality. Adjusting for the homicide rate diminishes both the magnitude of the association (from -.000229 to -.000123) and statistical significance substantially. Thus, lower homicide risk likely mediates this relationship. Aside from this age group, however, the only significant effects of the imprisonment rate on the mortality rates of black males are for infants and for men ages 65-74. And in both cases, the imprisonment rate was positively associated with mortality rates. For black women, on the other hand, there are no mortality-reducing benefits of imprisonment. Imprisonment rates never significantly associate with declines in their mortality risks, but they do associate with elevated mortality rates (at the .05 level) for women ages 35-44 and 55-64.

Taken together, results from these models support two main conclusions. First, and most provocatively, they indicate that increases in the imprisonment rate diminish the mortality risks of young black men, although this is certainly not to suggest that imprisonment improves the health and wellbeing of prisoners over the entire life-course. Indeed, results also suggest that the imprisonment rate is associated with substantial increases in the mortality risks of black men in a 
number of other age groups. Given what is known about the long-term costs of imprisonment for health (Massoglia 2008a, 2008b; Massoglia and Schnittker 2009; Schnittker and John 2007), these short-term benefits for one age group should not be oversold. Second, results indicate that this is the only group for which the imprisonment rate is associated with significant declines in mortality. All other significant effects (at the .05 level) showed that imprisonment compromises population health. This implies that although imprisonment might have some small short-term benefits for the mortality risk of one at-risk group, the negative effects of mass imprisonment on the health of African Americans and racial health inequalities are likely to be primarily negative.

\section{DISCUSSION, IMPLICATIONS, AND LIMITATIONS}

Drastic increases in American imprisonment over the last 35 years have produced extraordinary lifetime risks of imprisonment for American men (Bonczar 2003) and disparities in these risks (Pettit and Western 2004; Western and Wildeman 2009). Given this, it is unsurprising that the consequences of mass imprisonment have generated much interest. Unfortunately, the effects of mass imprisonment on (inequities in) population health have been virtually ignored (Beckfield and Krieger 2009:157; Wakefield and Uggen Forthcoming; but see Wildeman 2009a). The goal of the analysis herein was to extend research by considering the effects of imprisonment on (inequality in) population health using data from the United States between 1980 and 2004. My results support four main conclusions. First, the imprisonment rate is negatively associated with life expectancy and positively associated with the infant mortality rate for the total, black, and white populations. Interestingly, the effects were more substantial and more consistently significant for female life expectancy and the infant mortality rate than for male life expectancy. Thus, these results imply that imprisonment likely has negative effects on population 
health and that these effects are concentrated among those who have never been imprisoned. Second, many of these associations are quite substantial for blacks. According to my estimates, black life expectancy in 2004 would have been 0.8 years longer and the black infant mortality rate 2.2 per 1,000 lower absent increases in imprisonment since 1980. These findings are notable since they indicate that mass imprisonment played a key role in diminishing the health gains of blacks over this period. Third, imprisonment is consistently associated with racial inequity in both life expectancy and the infant mortality rate. Importantly, my results suggest that the 2004 black-white gap in the infant mortality rate would have been a staggering 23 percent lower had the imprisonment rate remained at its 1980 level. Finally, my results imply that increases in the imprisonment rate may diminish the mortality rates of young black men and that decreases in the homicide rate mediate this relationship. Taken together, my results suggest that imprisonment may affect population health and inequities in population health and that these effects may be substantial—especially for African Americans—but are also unlikely to be universally negative.

If the associations presented here represent causal relationships, they have at least three broad implications. First, and most provocatively, they highlight the dangerous lives of young black men by showing that increases in the imprisonment rate may diminish their mortality risk. For scholars of the penal system, this suggests that efforts to improve the health of black men through penal reform must be careful not to neglect the broader social forces that also shape their health and wellbeing. For scholars of racial inequality in contemporary America, this finding illustrates that young black men are so "against the wall” (Anderson 2008) that they may be safer in prison than on the streets. That young black men are so marginalized that they may be safer as captives than as free men illustrates just how far behind society has let these men fall. Maybe even more interestingly, the consistent, negative effects of the imprisonment rate on the health of 
black women and infants imply that the effects of imprisonment, paradoxically, may be more severe for those who never go to prison than for those who do. Recent reviews highlight the substantial consequences of mass imprisonment for those who never go to prison (Comfort 2007; Wakefield and Uggen Forthcoming; Wildeman and Western Forthcoming), but this finding is one of the first to demonstrate that the consequences of mass imprisonment may be greater for those never entering prison than those entering prison—at least in some areas. Finally, the results imply that the prison boom could have played some role in the declining health of Americans relative to those from other developed democracies (Berkman 2009). This implication is by far the most tentative of the three and requires empirical analysis using crossnational data, but it nonetheless suggests that mass imprisonment may influence crossnational health inequities.

Despite these interesting implications, this study has a number of noteworthy limitations. First, and probably most importantly, the measure of imprisonment used yields insight only into the immediate consequences of imprisonment for population health and inequality in population health. Given that some of the population-level health costs of imprisonment may not be known until many years after prisoners return to society (Johnson and Raphael 2009), this study may have underestimated the health effects of mass imprisonment. Thus, future research should consider using measures that capture the long-term effects of imprisonment on population health. Second, though I attempted to rule out concerns about unobserved heterogeneity and spuriousness driving the results, it is difficult to ever fully rule out these concerns-especially absent a natural experiment. Though some have used exogenous shocks in the imprisonment rate to identify a causal effect of imprisonment, many of these efforts have been roundly criticized (e.g., Levitt 1996). Finally, though the outcomes considered are excellent measures of population health, future research should also yield insight the effects of imprisonment on specific diseases 
and, possibly even more importantly, mental health. These limitations notwithstanding, this study paves the way for research on the effects of the prison boom on health inequities between developed democracies and within the United States. In so doing, it documents a new arena of inequities influenced by the sea change in American imprisonment of recent decades.

\section{REFERENCES}

Anderson, Elijah. 2008. “Against the Wall: Poor, Young, Black, and Male.” Pp. 1-27 in Against the Wall: Poor, Young, Black, and Male, edited by Elijah Anderson. Philadelphia: University of Pennsylvania Press.

Beckett, Katherine. 1997. Making Crime Pay: Law and Order in Contemporary American Politics. New York: Oxford University Press.

Beckfield, Jason. 2004. “Does Income Inequality Harm Health? New Cross-National Evidence.” Journal of Health and Social Behavior 45:231-248.

-----. 2006. “European Integration and Income Inequality.” American Sociological Review 71:964-985.

Beckfield, Jason, and Nancy Krieger. 2009. “Epi + demos + cracy: Linking Political Systems and Priorities to the Magnitude of Health Inequities_Evidence, Gaps, and a Research Agenda.” Epidemiologic Reviews 31:152-177.

Berkman, Lisa. 2009. “Social Epidemiology: Social Determinants of Health in the United States: Are We Losing Ground?” Annual Review of Public Health 30:27-41.

Bertrand, Marianne, Esther Duflo, and Sendhill Mullainathan. 2004. “How Much Should We Trust Differences-in-Differences Estimates?” Quarterly Journal of Economics 119:249275. 
Binswanger, Ingrid A., Marc F. Stern, Richard A. Deyo, Patrick J. Heagerty, Allen Cheadle, Joann G. Elmore, and Thomas D. Koepsell. 2007. "Release from Prison—A High Risk of Death for Former Inmates.” The New England Journal of Medicine 356:157-165.

Blumstein, Alfred, and Jacqueline Cohen. 1973. “A Theory of the Stability of Punishment.” Journal of Criminal Law and Criminology 64:198-207.

Bonczar, Thomas P. 2003. Prevalence of Imprisonment in the U.S. Population, 1974-2001. Bureau of Justice Statistics Special Report. Washington, DC: United States Department of Justice.

Braman, Donald. 2004. Doing Time on the Outside: Incarceration and Family Life in Urban America. Ann Arbor: University of Michigan Press.

Clavel, Francoise, Simone Benhamou, and Robert Flamant. 1987. “Decreased Mortality among Male Prisoners.” Lancet 330:1012-1014.

Clear, Todd R. 2008. “The Effects of High Imprisonment Rates on Communities.” Crime \& Justice 37:97-132.

Comfort, Megan. 2007. “Punishment Beyond the Legal Offender.” Annual Review of Law and Social Science 3:271-296.

-----. 2008. Doing Time Together: Love and Family in the Shadow of the Prison. Chicago, IL: University of Chicago Press.

Conley, Dalton, and Kristen W. Springer. 2001. "Welfare State and Infant Mortality.” The American Journal of Sociology 107:768-807.

Dooley, David, Jonathan Fielding, and Lennart Levi. 1996. “Health and Unemployment.” Annual Review of Public Health 17:449-465.

Ellwood, John W., and Joshua Guetzkow. 2009. "Footing the Bill: Causes and Budgetary 
Imprisonment and (Inequality in) Population Health

Consequences of State Spending on Corrections.” Pp. 207-238 in Do Prisons Make Us Safer? The Benefits and Costs of the Prison Boom, edited by Steven Raphael and Michael A. Stoll. New York: Russell Sage Press.

Farrell, Michael, and John Marsden. 2008. “Acute Risk of Drug-Related Death among Newly Released Prisoners in England and Wales.” Addiction 103:251-255.

Fryer, Roland G., Jr., Paul S. Heaton, Steven D. Levitt, and Kevin M. Murphy. 2005.

“Measuring the Impact of Crack Cocaine.” NBER Working Paper \#11318.

Geller, Amanda, Irwin Garfinkel, and Bruce Western. Forthcoming. “Incarceration and Support for Children in Fragile Families.” Demography.

Geronimus, Arline T. 1992. “The Weathering Hypothesis and the Health of African American Women and Infants: Evidence and Speculations.” Ethnicity and Disease 2:207-221.

Goffman, Alice. 2009. “On the Run: Wanted Men in a Philadelphia Ghetto.” American Sociological Review 74:339-357.

Green, Kerry M., Margaret E. Ensminger, Judith A. Robertson, and Hee-Soon Juon. 2006. “Impact of Adult Sons’ Incarceration on African American Mothers’ Psychological Distress.” Journal of Marriage and Family 68:430-441.

Halaby, Charles. 2004. “Panel Models in Sociological Research: Theory into Practice.” Annual Review of Sociology 30:507-544.

Hall, Peter A., and Michelle Lamont. 2009. Successful Societies: How Institutions and Culture Affect Health. New York, NY: Cambridge University Press.

Harper, Sam, John Lynch, Scott Burris, and George Davey Smith. 2007. “Trends in the BlackWhite Life Expectancy Gap in the United States, 1983-2003.” JAMA 297:1224-1232.

Jacobs, David and Ronald E. Helms. 1996. “Toward a Political Model of Incarceration: A Time- 
Imprisonment and (Inequality in) Population Health

Series Examination of Multiple Explanations for Prison Admission Rates.” American Journal of Sociology 102:323-57.

Johnson, Rucker, and Steven Raphael. 2009. “The Effects of Male Incarceration Dynamics on Acquired Immune Deficiency Syndrome Infection Rates among African American Women and Men.” Journal of Law and Economics 52:251-293.

LaVeist, Thomas A. 1992. “The Political Empowerment and Health Status of AfricanAmericans: Mapping a New Territory.” American Journal of Sociology 97:1080-1095.

Levitt, Steven D. 1996. “The Effect of Prison Population Size on Crime Rates: Evidence from Prison Overcrowding Litigation.” Quarterly Journal of Economics 111:319-351.

Lopoo, Leonard M., and Bruce Western. 2005. “Incarceration and the Formation and Stability of Marital Unions.” Journal of Marriage and Family 67:721-734.

Massoglia, Michael. 2008a. “Incarceration as Exposure: The Prison, Infectious Disease, and Other Stress-Related Illnesses.” Journal of Health and Social Behavior 49:56-71.

-----. 2008b. “Incarceration, Health, and Racial Disparities in Health.” Law \& Society Review 42:275-306.

Massoglia, Michael, and Jason Schnittker. 2009. “No Real Release.” Contexts 8:38-42.

Mumola, Christopher J. 2007. Medical Causes of Death in State Prisons, 2001-2004. Bureau of Justice Statistics Data Brief. U.S. Department of Justice, Washington: DC.

Nickell, Stephen. 1981. “Biases in Dynamic Models with Fixed Effects.” Econometrica 49:14171426.

Pager, Devah. 2003. “The Mark of a Criminal Record.” American Journal of Sociology 108:937975.

Papachristos, Andrew V. 2009. "Murder by Structure: Dominance Relations and the Social 
Imprisonment and (Inequality in) Population Health

Structure of Gang Homicide.” American Journal of Sociology 115:74-128.

Pettit, Becky, and Bruce Western. 2004. "Mass Imprisonment and the Life Course: Race and Class Inequality in U.S. Incarceration.” American Sociological Review 69:151-169.

Rosen, David L., Victor J. Schoenbach, and David A. Wohl. 2008. “All-Cause and CauseSpecific Mortality among Men Released from State Prison, 1980-2005.” American Journal of Public Health 98:2278-2284.

Ruhm, Christopher J. 2000. “Are Recessions Good for Your Health?” Quarterly Journal of Economics 115:617-650.

Schnittker, Jason, and Andrea John. 2007. “Enduring Stigma: The Long-Term Effects of Incarceration on Health.” Journal of Health and Social Behavior 48:115-130.

Stuckler, David, Sanjay Basu, Martin McKee, and Lawrence King. 2008. "Mass Incarceration Can Explain Population Increases in TB and Multidrug-Resistant TB in European and Central Asian Countries.” Proceedings of the National Academy of Sciences 105:1328013285.

Sutton, John R. 2000. "Imprisonment and Social Classification in Five Common-Law Democracies, 1955-1985.” American Journal of Sociology 106:350-86.

Thomas, James C., and Elizabeth Torrone. 2006. "Incarceration as Forced Migration: Effects on Selected Community Health Outcomes.” American Journal of Public Health 96:17621765.

Wakefield, Sara, and Christopher Uggen. Forthcoming. "Incarceration and Stratification.” Annual Review of Sociology.

Western, Bruce. 2002. “The Impact of Incarceration on Wage Mobility and Inequality.” American Sociological Review 67:477-498. 
-----. 2006. Punishment and Inequality in America. New York: Russell Sage Press.

Western, Bruce, and Christopher Wildeman. 2009. “The Black Family and Mass Incarceration.” Annals of the American Academy of Political and Social Science 621:221-242.

Wildeman, Christopher. 2009a. “Imprisonment and Infant Mortality.” PSC Research Report No. 09-692.

----. 2009b. "Parental Imprisonment, the Prison Boom, and the Concentration of Childhood Disadvantage.” Demography 46:265-280.

----. Forthcoming. “Paternal Incarceration and Children’s Physically Aggressive Behaviors: Evidence from the Fragile Families and Child Wellbeing Study.” Social Forces. Wildeman, Christopher, and Bruce Western. Forthcoming. "Incarceration in Fragile Families.” The Future of Children.

Yates, Jeff, and Richard C. Fording. 2005. "Politics and State Punitiveness in Black and White.” Journal of Politics 67:1099-1121. 
Imprisonment and (Inequality in) Population Health

Table 1. Descriptive Statistics and Data Sources $(N=695)$

\begin{tabular}{|c|c|c|c|}
\hline Covariate & Mean & (SD) & Source \\
\hline \multicolumn{4}{|l|}{ Life Expectancy (Years) } \\
\hline Total & 74.5 & (1.6) & Calculated using CDC mortality data \\
\hline Total Male & 71.1 & (2.0) & Calculated using CDC mortality data \\
\hline Total Female & 77.9 & $(1.2)$ & Calculated using CDC mortality data \\
\hline White & 75.3 & (1.3) & Calculated using CDC mortality data \\
\hline White Male & 72.0 & (1.7) & Calculated using CDC mortality data \\
\hline White Female & 78.5 & (1.0) & Calculated using CDC mortality data \\
\hline Black & 69.7 & (1.8) & Calculated using CDC mortality data \\
\hline Black Male & 65.5 & $(2.2)$ & Calculated using CDC mortality data \\
\hline Black Female & 73.7 & (1.4) & Calculated using CDC mortality data \\
\hline White - Black & 5.6 & (1.2) & Calculated using CDC mortality data \\
\hline White Male - Black Male & 6.5 & (1.5) & Calculated using CDC mortality data \\
\hline White Female - Black Female & 4.8 & $(1.0)$ & Calculated using CDC mortality data \\
\hline \multicolumn{4}{|l|}{ Infant Mortality Rate (per 1,000) } \\
\hline Total & 9.4 & $(2.2)$ & Calculated using CDC mortality data \\
\hline White & 7.6 & (1.7) & Calculated using CDC mortality data \\
\hline Black & 16.5 & (3.4) & Calculated using CDC mortality data \\
\hline Black - White & 7.1 & (2.3) & Calculated using CDC mortality data \\
\hline Imprisonment Rate (per 1,000) & 3.2 & (1.6) & Bureau of Justice Statistics \\
\hline Probation Rate (per 1,000) & 9.8 & (6.0) & Bureau of Justice Statistics \\
\hline Total Crime Rate (per 100,000) & 572.3 & (219.5) & Bureau of Justice Statistics \\
\hline Homicide Rate (per 100,000) & 8.0 & (3.2) & Bureau of Justice Statistics \\
\hline Total Public Health Expend. (\$1000s per Capita) & 3.9 & (1.1) & Center for Medicare and Medicaid Services \\
\hline Percent Urban & 73.2 & (12.8) & Decennial Census \\
\hline Percent Foreign-Born & 6.3 & $(5.7)$ & Decennial Census \\
\hline Percent Hispanic & 6.3 & (7.5) & Decennial Census \\
\hline Percent Black & 15.2 & (8.8) & Decennial Census \\
\hline \multicolumn{4}{|l|}{ Percent of the Population } \\
\hline Aged 0-14 & 21.5 & (1.4) & Decennial Census \\
\hline Aged 15-34 & 31.0 & (3.1) & Decennial Census \\
\hline Aged 35-54 & 26.1 & (3.2) & Decennial Census \\
\hline Aged 55+ & 21.3 & (2.2) & Decennial Census \\
\hline Percent College Degree (Over Age 25) & 21.6 & (2.2) & Decennial Census and Statistical Abstracts \\
\hline Gross State Product ( $\$ 1000$ s per Capita) & 31.6 & $(7.1)$ & Bureau of Economic Analysis \\
\hline Unemployment Rate & 6.1 & (2.1) & Bureau of Labor Statistics \\
\hline AFDC Caseloads (per 1,000) & 13.2 & (5.7) & Department of Health and Human Services \\
\hline AFDC/TANF + Food Stamp (\$100s per Month) $)^{\mathrm{a}}$ & 9.9 & (1.9) & House of Representatives Green Books \\
\hline Percent in Poverty & 13.7 & $(4.2)$ & Census Bureau \\
\hline Doctors (per 100,000) & 218.3 & $(61.8)$ & Statistical Abstracts \\
\hline Percent Nonmarital Births & 29.2 & $(7.1)$ & National Vital Statistics Reports \\
\hline Percent Premature Births & 11.2 & (1.8) & National Vital Statistics Reports \\
\hline Percent Low Birthweight Births & 7.6 & $(1.1)$ & National Vital Statistics Reports \\
\hline Democrat Governor & 50.6 & $(50.0)$ & Council of State Governments \\
\hline Percent Upper House Democrat & 61.4 & (16.9) & Council of State Governments \\
\hline Percent Lower House Democrat & 61.7 & (15.3) & Council of State Governments \\
\hline
\end{tabular}

Note: All dollar values are deflated to represent real 2005 dollars.

${ }^{\mathrm{a}}$ Combined AFDC/TANF plus Food Stamp benefit was calculated for a family of four. 
Table 2. Results from OLS Regression Models with State FE, Year FE, and an AR(1) Adjustment Predicting Population Health by the Imprisonment Rate $(N=695)$

\begin{tabular}{|c|c|c|c|c|c|c|c|c|}
\hline \multirow{2}{*}{$\begin{array}{l}\text { Covariate } \\
\text { Imprisonment Rate }\end{array}$} & \multicolumn{2}{|c|}{$\begin{array}{c}\text { Total Life } \\
\text { Expectancy }\end{array}$} & \multicolumn{2}{|c|}{$\begin{array}{c}\text { Male Life } \\
\text { Expectancy }\end{array}$} & \multicolumn{2}{|c|}{$\begin{array}{l}\text { Female Life } \\
\text { Expectancy }\end{array}$} & \multicolumn{2}{|c|}{ Infant Mortality } \\
\hline & $-.08 * *$ & $(.03)$ & $-.07 \#$ & $(.04)$ & $-.10 * *$ & $(.04)$ & $.15 *$ & $(.07)$ \\
\hline Probation Rate & -.01 & $(.01)$ & -.00 & $(.01)$ & -.01 & $(.01)$ & -.00 & $(.01)$ \\
\hline Total Crime Rate & $-.00 \#$ & $(.00)$ & $-.00 * *$ & $(.00)$ & $-.00 \#$ & $(.00)$ & .00 & $(.00)$ \\
\hline Homicide Rate & $-.03 * * *$ & $(.01)$ & $-.04 * * *$ & $(.01)$ & $-.03 * *$ & $(.01)$ & $.04 \#$ & $(.02)$ \\
\hline Total Public Health Expend. & .03 & $(.11)$ & .03 & $(.12)$ & .10 & $(.12)$ & $-.42 *$ & $(.21)$ \\
\hline Percent Urban & .04 & $(.02)$ & .03 & $(.02)$ & .04 & $(.02)$ & -.02 & $(.03)$ \\
\hline Percent Foreign-Born & $.21 * * *$ & $(.05)$ & $.22 * * *$ & $(.05)$ & $.13^{* *}$ & $(.05)$ & -.12 & $(.07)$ \\
\hline Percent Hispanic & -.04 & $(.04)$ & -.06 & $(.04)$ & .02 & $(.04)$ & .03 & $(.06)$ \\
\hline Percent Black & .00 & $(.03)$ & -.01 & $(.04)$ & .03 & $(.04)$ & .01 & $(.06)$ \\
\hline \multicolumn{9}{|l|}{ Percent of the Population } \\
\hline Aged 0-14 & -.02 & $(.05)$ & -.08 & $(.06)$ & .04 & $(.06)$ & .15 & $(.11)$ \\
\hline Aged 15-34 & $-.21 * * *$ & $(.03)$ & $-.27 * * *$ & $(.06)$ & $-.13 * *$ & $(.05)$ & .15 & $(.10)$ \\
\hline Aged 55+ & -.16 & $(.07)$ & $-.25 * * *$ & $(.07)$ & -.05 & $(.07)$ & .07 & $(.11)$ \\
\hline Percent College Degree & -.01 & $(.01)$ & -.01 & $(.01)$ & -.01 & $(.01)$ & .02 & $(.02)$ \\
\hline Gross State Product & -.02 & $(.01)$ & -.01 & $(.01)$ & -.01 & $(.01)$ & .01 & $(.02)$ \\
\hline Unemployment Rate & $.02 \#$ & $(.01)$ & $.03 *$ & $(.01)$ & .01 & $(.01)$ & -.00 & $(.03)$ \\
\hline AFDC Caseloads & $-.02 * *$ & $(.01)$ & $-.02 *$ & $(.01)$ & $-.04 * * *$ & $(.01)$ & -.00 & $(.02)$ \\
\hline AFDC/TANF + FS Benefit & .00 & $(.01)$ & .00 & $(.01)$ & .00 & $(.01)$ & -.00 & $(.03)$ \\
\hline Percent in Poverty & -.00 & $(.00)$ & -.01 & $(.01)$ & .00 & $(.01)$ & .01 & $(.01)$ \\
\hline Doctors & -.00 & $(.00)$ & -.00 & $(.00)$ & -.00 & $(.00)$ & .00 & $(.00)$ \\
\hline Percent Nonmarital & -.01 & $(.01)$ & -.01 & $(.01)$ & -.01 & $(.01)$ & .02 & $(.02)$ \\
\hline Percent Premature & .03 & $(.03)$ & .01 & $(.03)$ & .03 & $(.03)$ & .08 & $(.07)$ \\
\hline Percent Low Birthweight & $-.14 * *$ & $(.05)$ & $-.16^{* *}$ & $(.05)$ & $-.13^{*}$ & $(.05)$ & $.52 * * *$ & (.13) \\
\hline Democrat Governor & .00 & $(.00)$ & .00 & $(.00)$ & .00 & $(.00)$ & .00 & $(.00)$ \\
\hline Percent Upper Democrat & .00 & $(.00)$ & -.00 & $(.00)$ & .00 & $(.00)$ & .00 & $(.00)$ \\
\hline Percent Lower Democrat & .00 & $(.00)$ & .00 & $(.00)$ & .00 & $(.00)$ & .00 & $(.00)$ \\
\hline Intercept & $-1.00 * * *$ & $(.08)$ & $-.88 * * *$ & $(.11)$ & $-.97 * * *$ & $(.11)$ & .42 & $(.34)$ \\
\hline$p$ & \multicolumn{2}{|c|}{.77} & \multicolumn{2}{|c|}{.71} & \multicolumn{2}{|c|}{.69} & \multicolumn{2}{|c|}{.49} \\
\hline $\mathrm{R}^{2}$ & \multicolumn{2}{|c|}{.99} & \multicolumn{2}{|c|}{.99} & \multicolumn{2}{|c|}{.99} & \multicolumn{2}{|c|}{.82} \\
\hline
\end{tabular}

Notes: All t-tests for imprisonment are two-sided. Standard errors are shown in parentheses. $\# \mathrm{p}<.10 ; * p<.05 ; * * p<.01 ; * * * p<.001$ 
Table 3. Estimated Effects of the Imprisonment Rate on Population Health for Whites and Blacks and Inequality in Population Based on OLS Regression Models with State FE, Year FE, and an AR(1) Adjustment ( $N=695)$

\begin{tabular}{lllllll}
\hline & \multicolumn{3}{c}{ Whites } & \multicolumn{2}{c}{ Blacks } & \multicolumn{2}{c}{ Inequality $^{\mathrm{a}}$} \\
\hline & & & & & & \\
Total Life Expectancy & $-.06 \#$ & $(.03)$ & $-.23^{* *}$ & $(.08)$ & $.14^{*}$ & $(.07)$ \\
Male Life Expectancy & -.04 & $(.04)$ & $-.17 \#$ & $(.10)$ & .12 & $(.09)$ \\
Female Life Expectancy & $-.09^{*}$ & $(.04)$ & $-.23^{* *}$ & $(.08)$ & .12 & $(.07)$ \\
Infant Mortality Rate & $.14^{*}$ & $(.06)$ & $.61^{*}$ & $(.24)$ & $.46 \#$ & $(.24)$ \\
\hline
\end{tabular}

Notes: All models include the full set of controls shown in Table 2. All coefficients other than imprisonment were suppressed in order to conserve space. The full set of results is available upon request from the author. All t-tests are two-sided. Standard errors are shown in parentheses.

${ }^{a}$ Positive coefficients represent increases in inequality in every case.

$\# \mathrm{p}<.10 ; * p<.05 ;{ }^{* *} p<.01 ; * * * p<.001$ 
Table 4. Observed Population Health in 1980 and Predicted Population Health in 2004 Based on Observed Increases in Imprisonment and No Increase in Imprisonment

\begin{tabular}{lccc} 
& & & \\
& Observed in 1980 & Predicted in 2004, & Predicted in 2004, \\
2004 Imprisonment & 1980 Imprisonment \\
\hline Total Life Expectancy & 72.5 & 76.1 & 76.4 \\
Total Male Life Expectancy & 68.6 & 73.5 & 73.8 \\
Total Female Life Expectancy & 76.5 & 78.9 & 79.3 \\
Total Infant Mortality & 13.0 & 7.4 & 6.9 \\
White Total Life Expectancy & & & 77.0 \\
White Male Life Expectancy & 73.3 & 76.8 & 74.4 \\
White Female Life Expectancy & 69.4 & 79.2 & 79.8 \\
White Infant Mortality & 77.3 & 6.0 & 5.5 \\
& 10.8 & & 73.0 \\
Black Total Life Expectancy & & 72.2 & 69.4 \\
Black Male Life Expectancy & 67.6 & 68.8 & 76.2 \\
Black Female Life Expectancy & 63.2 & 75.4 & 10.7 \\
Black Infant Mortality & 72.1 & 12.9 & 4.2 \\
Inequality in Total Life Expectancy & 21.7 & 4.7 & 5.1 \\
Inequality in Male Life Expectancy & 5.7 & 5.5 & 3.7 \\
Inequality in Female Life Expectancy & 6.2 & 4.1 & 5.3 \\
Inequality in Infant Mortality & 5.2 & 6.9 & \\
\hline
\end{tabular}

Note: All predictions based on results from corresponding models in Tables 2 and 3. 
Table 5. Estimated Effects of Imprisonment on Age-Specific Mortality Rates for the Total Population, Blacks, and Whites by Sex Based on OLS Regression Models with State FE, Year FE, and an AR(1) Adjustment $(N=695)$

\begin{tabular}{|c|c|c|c|c|c|c|}
\hline \multirow[b]{2}{*}{ Estimated Imprisonment Effect at Age } & \multicolumn{2}{|c|}{ Total } & \multicolumn{2}{|c|}{ White } & \multicolumn{2}{|c|}{ Black } \\
\hline & Men & Women & Men & Women & Men & Women \\
\hline$<1$ & $.000156 \#$ & $.000124 \#$ & .000107 & $.000159 *$ & $.000745 *$ & .000414 \\
\hline $1-4$ & .000007 & $.000011 \#$ & .000007 & $.000015^{*}$ & .000020 & .000023 \\
\hline $5-9$ & -.000002 & -.000001 & -.000002 & -.000004 & -.000001 & -.000002 \\
\hline $10-14$ & .000001 & $.000013^{* *}$ & .000006 & $.000018^{* * *}$ & -.000018 & .000004 \\
\hline $15-19$ & -.000023 & .000001 & .000007 & .000004 & -.000037 & .000004 \\
\hline $20-24$ & -.000019 & .000012 & .000002 & .000010 & $-.000121 *$ & .000016 \\
\hline $25-34$ & -.000014 & .000010 & -.000007 & .000008 & -.000082 & .000013 \\
\hline $35-44$ & .000034 & $.000048 * * *$ & .000036 & $.000044^{* *}$ & .000077 & $.000103^{*}$ \\
\hline $45-54$ & .000030 & .000017 & .000046 & .000020 & -.000003 & -.000012 \\
\hline $55-64$ & .000068 & $.000080 *$ & .000040 & $.000073 *$ & .000246 & $.000307 *$ \\
\hline $65-74$ & -.000031 & .000062 & $-.000197 \#$ & .000062 & $.000898 *$ & $.000357 \#$ \\
\hline $75-84$ & -.000102 & .000043 & -.000268 & .000042 & .000274 & .000566 \\
\hline $85+$ & .000638 & $.001193 * *$ & .000289 & $.001131^{* *}$ & .001886 & -.000023 \\
\hline
\end{tabular}

Notes: All models include the full set of controls shown in Table 2. All coefficients other than imprisonment were suppressed in order to conserve space. The full set of results is available upon request from the author. All t-tests are two-sided. Standard errors are suppressed in the interest of conserving space and are also available upon request from the author.

$\# \mathrm{p}<.10 ; * p<.05 ; * * p<.01 ; * * * p<.001$ 
Figure 1. Changes in Life Expectancy at Birth and the Infant Mortality Rate, 1980-2004
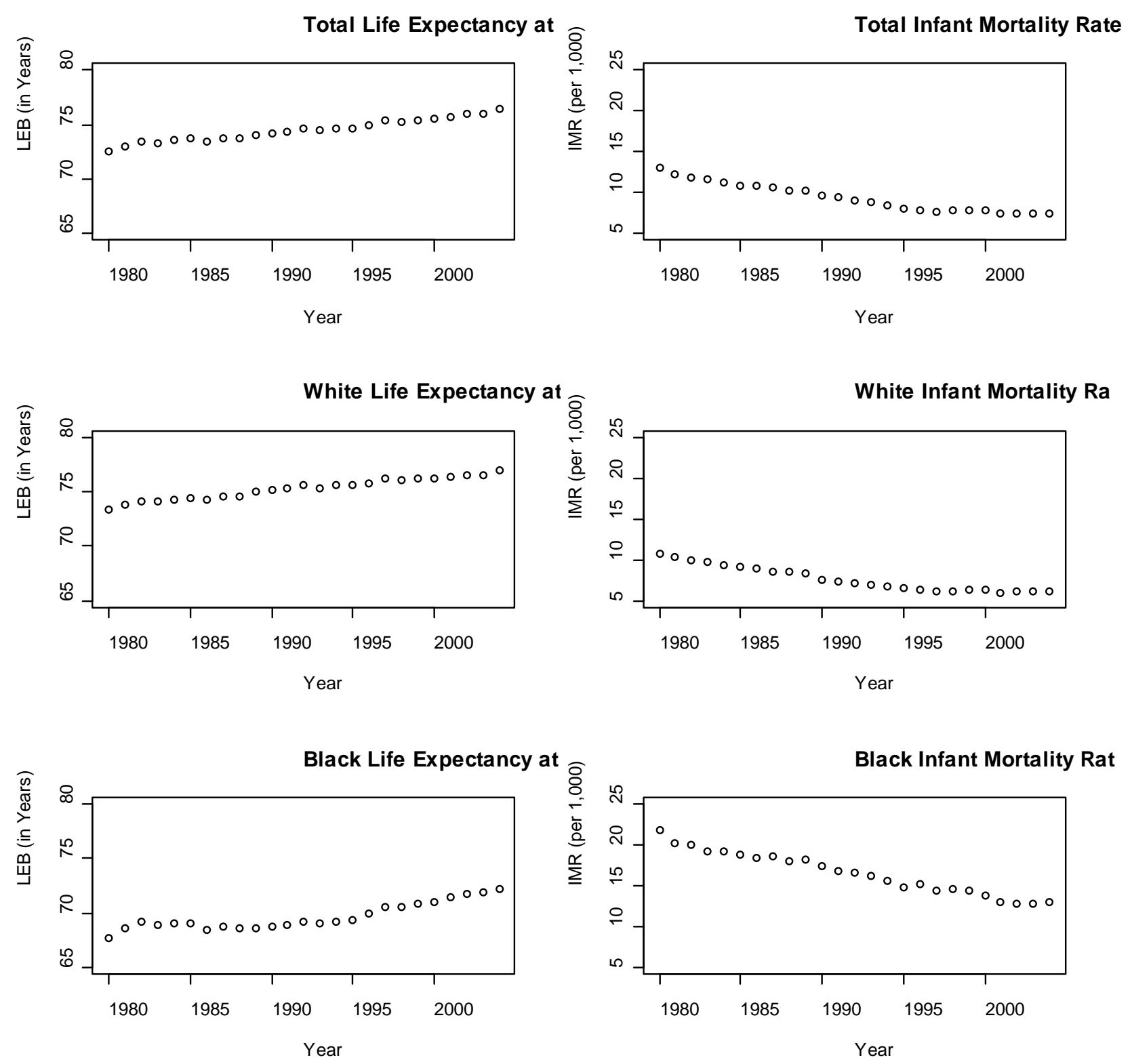

Note: Figures rely only on data for which information on all outcomes was available ( $N=695)$. 
Figure 2. Changes in Mortality Rates for Young White and Black Men, 1980-2004
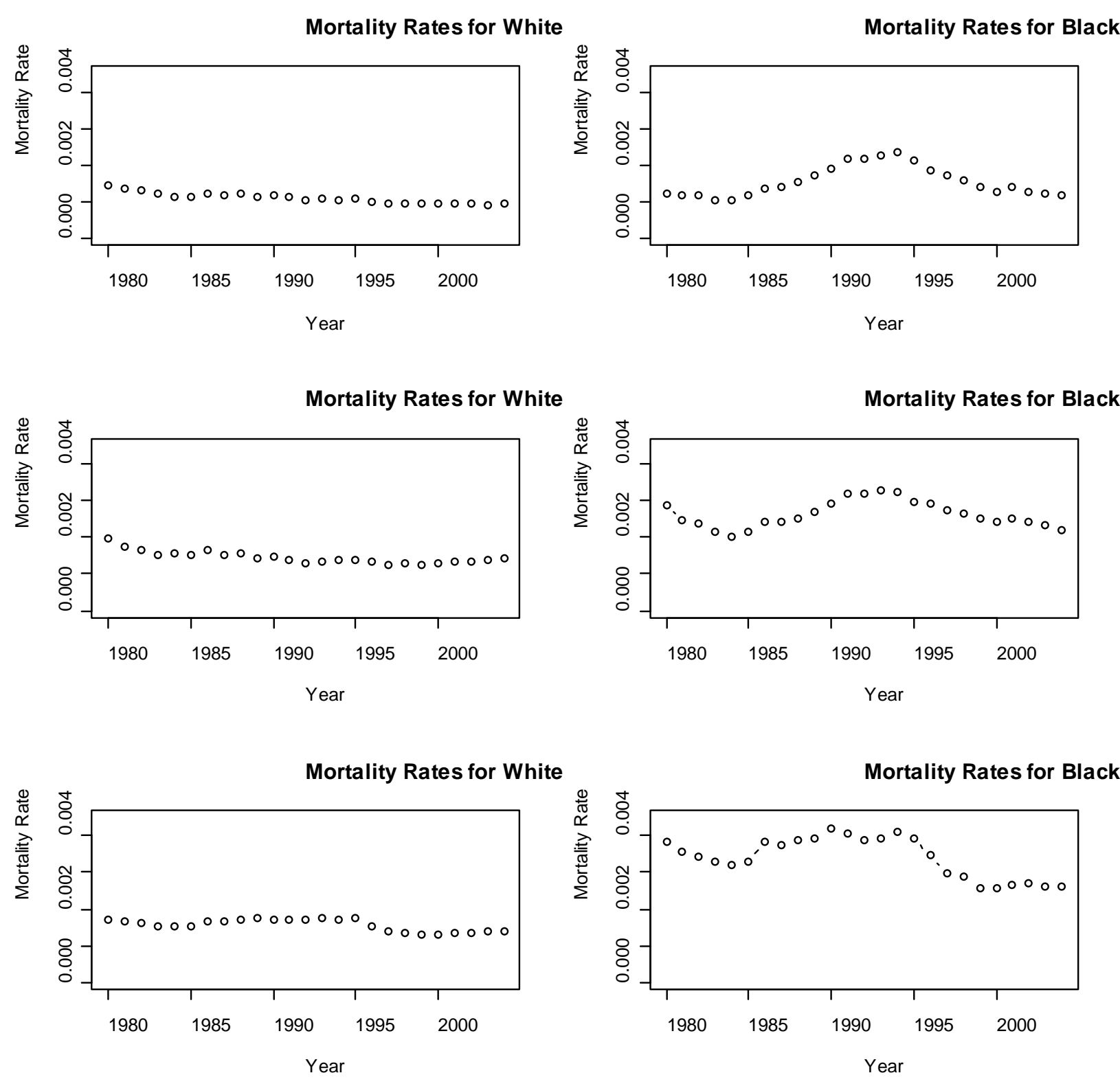

Note: Figures rely only on data for which information on all outcomes was available ( $N=695)$. 
Imprisonment and (Inequality in) Population Health

Figure 3. Box Plots of State Imprisonment Rates, 1980-2004 
Table A1: States Included in the Analysis by Year

\begin{tabular}{|c|c|c|c|c|c|c|c|c|c|c|c|c|c|c|c|c|c|c|c|c|c|c|c|c|c|}
\hline Available & 80 & 81 & 82 & 83 & 84 & 85 & 86 & 87 & 88 & 89 & 90 & 91 & 92 & 93 & 94 & 95 & 96 & 97 & 98 & 99 & 00 & 01 & 02 & 03 & 04 \\
\hline Alabama & * & * & * & * & * & * & * & * & * & * & * & * & * & $*$ & * & * & * & * & * & * & * & * & * & * & * \\
\hline $\begin{array}{l}\text { Alaska } \\
\text { Arizonan }\end{array}$ & & & & & & & & & * & $*$ & & & * & * & * & $*$ & $*$ & $*$ & & * & & & * & $*$ & $*$ \\
\hline $\begin{array}{l}\text { Arizona } \\
\text { Arkansas }\end{array}$ & * & * & * & * & * & * & * & * & * & * & * & * & * & * & * & * & * & * & * & * & * & * & * & * & * \\
\hline California & * & * & * & * & * & * & * & * & * & * & * & * & * & * & * & * & * & * & * & * & * & * & * & * & * \\
\hline Colorado & * & * & * & & * & * & * & * & & * & $*$ & & & * & & * & & & & * & & & & * & \\
\hline $\begin{array}{l}\text { Connecticut } \\
\text { Delaware }\end{array}$ & * & * & & & * & * & * & * & * & * & * & * & * & * & * & * & * & * & * & * & * & * & * & * & * \\
\hline & " & ${ }^{*}$ & & & ${ }^{*}$ & & F & * & & * & * & & & & & & & * & & & * & & & & \\
\hline Florida & * & * & * & * & * & * & * & * & * & * & * & * & * & * & * & * & * & * & * & * & * & * & * & * & * \\
\hline \multirow{2}{*}{\multicolumn{26}{|c|}{ Hawaii }} \\
\hline & & & & & & & & & & & & & & & & & & & & & & & & & \\
\hline $\begin{array}{l}\text { Idaho } \\
\text { Illinois }\end{array}$ & * & * & * & * & * & * & * & * & * & * & * & * & * & * & * & * & * & * & * & * & * & * & * & * & * \\
\hline $\begin{array}{l}\text { Indiana } \\
\text { Iowa }\end{array}$ & * & * & * & * & * & * & * & * & * & * & * & * & * & * & * & * & * & * & * & * & * & * & * & * & * \\
\hline $\begin{array}{l}\text { lowa } \\
\text { Kansas }\end{array}$ & & * & & & * & & & * & $*$ & & & * & * & * & * & & * & $*$ & $*$ & & $*$ & $*$ & & & $*$ \\
\hline Kentucky & * & * & * & * & * & * & * & & * & & & * & * & * & * & * & * & * & * & * & * & & & * & * \\
\hline Louisiana & * & * & * & * & * & * & * & * & * & * & * & * & * & * & * & * & * & * & * & * & * & * & * & * & * \\
\hline $\begin{array}{l}\text { Maine } \\
\text { Maryland }\end{array}$ & * & * & * & $*$ & * & $*$ & * & * & $*$ & * & * & * & * & * & * & $*$ & * & * & $*$ & * & $*$ & * & $*$ & * & $*$ \\
\hline Massachusetts & * & * & * & * & * & * & & & * & & * & * & * & * & * & * & * & * & & * & * & * & * & * & * \\
\hline Michigan & * & * & * & * & * & * & * & * & * & * & * & * & * & * & * & * & * & * & * & * & * & * & * & * & * \\
\hline Minnesota & & & & & & * & & & & & & & & & * & & & & & & * & * & * & & * \\
\hline Mississippi & * & $*$ & * & * & * & $*$ & $*$ & * & * & * & * & $*$ & * & * & $*$ & * & * & $*$ & * & * & * & * & * & * & * \\
\hline Missouri & * & * & * & * & * & * & * & * & * & * & * & * & * & * & * & * & * & * & * & * & * & * & * & * & * \\
\hline \multirow{2}{*}{\multicolumn{26}{|c|}{$\begin{array}{l}\text { Montana } \\
\text { Nebraska }\end{array}$}} \\
\hline \multirow{2}{*}{\multicolumn{26}{|c|}{ Nevada }} \\
\hline & & & & & & & & & & & & & & & & & & & & & & & & & \\
\hline $\begin{array}{l}\text { New Hampshire } \\
\text { New Jersey }\end{array}$ & $*$ & * & * & * & $*$ & * & * & $*$ & $*$ & $*$ & $*$ & * & $*$ & $*$ & * & $*$ & * & $*$ & * & * & $*$ & $*$ & $*$ & * & * \\
\hline New Mexico & & . & " & & 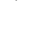 & 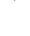 & 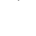 & " & & " & 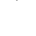 & & " & & & 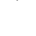 & & 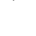 & 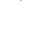 & & 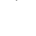 & & " & 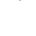 & \\
\hline New York & * & * & * & * & * & * & * & * & * & * & * & * & * & * & * & * & * & * & * & * & * & * & * & * & * \\
\hline North Carolina & * & * & * & * & * & * & * & * & * & * & * & * & * & * & * & * & * & * & * & * & * & * & * & * & * \\
\hline $\begin{array}{l}\text { North Dakota } \\
\text { Ohio }\end{array}$ & * & * & * & $*$ & * & $*$ & * & * & * & * & * & * & * & * & * & * & * & * & * & * & * & * & * & * & $*$ \\
\hline Oklahoma & * & * & * & * & * & & & & * & * & & & & * & * & * & & & & & & * & & * & * \\
\hline $\begin{array}{l}\text { Oregon } \\
\text { Pennsylvania }\end{array}$ & * & * & * & $*$ & * & * & * & * & * & * & * & * & * & * & * & * & * & * & * & * & * & * & * & * & * \\
\hline Rhode Island & & & & & & & & & & & & & & & & & & & & & & & & & \\
\hline South Carolina & * & * & $*$ & * & $*$ & * & $*$ & * & * & * & * & * & * & * & * & $*$ & * & $*$ & * & $*$ & * & * & * & * & * \\
\hline $\begin{array}{l}\text { South Dakota } \\
\text { Tennessee }\end{array}$ & * & * & * & * & * & * & * & * & * & * & * & * & * & * & * & * & * & $*$ & $*$ & * & * & $*$ & * & $*$ & * \\
\hline Texas & * & * & * & * & * & * & * & * & * & * & * & * & * & * & * & * & * & * & * & * & * & * & * & * & * \\
\hline \multicolumn{26}{|l|}{ 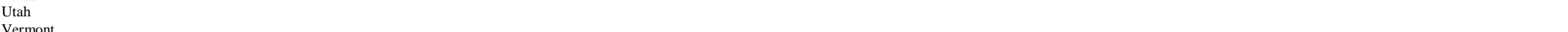 } \\
\hline & * & $*$ & $*$ & $*$ & $*$ & $*$ & $*$ & $*$ & $*$ & * & $*$ & $*$ & * & $*$ & * & $*$ & $*$ & $*$ & $*$ & $*$ & $*$ & $*$ & $*$ & $*$ & $*$ \\
\hline $\begin{array}{l}\text { Virginia } \\
\text { Washington }\end{array}$ & ${ }^{*}$ & $*$ & $*$ & $F^{*}$ & $*$ & * & 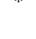 & " & F & $*$ & & * & " & * & $*$ & & $*$ & $*$ & & * & * & & * & * & \\
\hline $\begin{array}{l}\text { West Virginia } \\
\text { Wisconsin }\end{array}$ & * & * & * & * & * & * & * & * & * & * & * & * & * & * & * & * & * & * & * & * & * & * & * & * & $*$ \\
\hline
\end{tabular}

